\title{
Uncertainty in Macroeconomics and the Microeconomics of Uncertainty*
}

\author{
by Henri Loubergé**
}

\begin{abstract}
Professor von Furstenberg's lecture on "Uncertainty in Macroeconomics" [1988] has presented a very comprehensive survey of the problems raised in current macroeconomic research. Such a survey was very much needed, because for those economists who do not specialize in macro-theory, there is a widespread opinion that the important issues raised by risk and uncertainty have not been yet seriously considered at the global level. These issues remain largely limited to the fields of microeconomics (Hey [1979]), finance (Copeland and Weston [1974]) and international trade (Helpman and Razin [1978]), with some advances into international monetary economics (Frenkel [1983]).
\end{abstract}

In microeconomic theory there is already a long tradition of interest in risk and uncertainty. The relevance of these concepts for the understanding of entrepreneurship and the analysis of market mechanisms was recognized as early as 1921 in the famous book by Frank Knight on Risk, Uncertainty and Profit. The real start of an economic science taking risk and behavior towards riks into account is however credited to the pathbreaking book by John von Neumann and Oskar Morgenstern Theory of Games and Economic Behavior, published in 1947, 40 years ago. Since that time, the most important advances in micro-economic theory were closely associated to the concepts of risk, uncertainty and information. As a result economic theory is now in a much better position to explain how consumers, producers and investors behave, and to analyse how resources are allocated and market imperfections arise. A long list of well-known economists is associated to successive waves of development in the microeconomics of uncertainty. These are, among others, Friedman, Savage, Arrow, Pratt and Ross for the theory of risk-aversion; Sandmo, Leland, Drèze and Modigliani for its application to the traditional microeconomic chapters on consumer behavior, the theory of the firm and the theory of the labor market; Arrow and Debreu for the theory of general equilibrium under uncertainty; Radner, Stiglitz, Rothschild, Grossmann, Laffont, Hellwig and many others for the economics of information and its recent extension: the theory of contracts.

\footnotetext{
* Comment prepared for the 11th Annual Lecture of the Geneva Association, given at the University of Cologne on 29 May 1987.

** Professor of Political Economy, University of Geneva.
} 
All these important advances in microeconomic research brought about huge improvements in our understanding of how individual decisions interact in a market economy. But more than that, they also allowed economic theory to have something to say about wide domains of economic reality which simply could not be rigorously and convincingly analyzed in the absence of a risk-theoretical framework. Among these domains the most obvious is insurance which benefitted from the work of Arrow, Borch, Raviv, Pauly, Rothschild and Stiglitz, and more recently from the portfolio approach to insurance proposed by Kahane, Doherty and Schlesinger, and Mayers and Smith.

Although the developments in the economics of insurance were amazing (and much needed), they were nevertheless surpassed by those observed in finance where theoretical research resulted in new ideas which changed completely the way of thinking about financial markets, investment and corporate finance. Here again, the advances took place in close connection with the economics of uncertainty. A theory of finance became possible because microeconomic theory provided the philosophical paradigm and the mathematical tools which were needed to put financial problems under scrutiny. In finance too, several waves of development were observed over the past 30 years; it started in the fifties with the portfolio theory of Markowitz and Tobin; the mean-variance approach culminated at the end of the sixties with the Capital Asset Pricing Model (CAPM) developed by Sharpe, Lintner and Mossin, and with the Efficient Market Hypothesis of Fama providing an added argument in favour of investment portfolio diversification. In the seventies we witnessed the development of the Ross and Roll Arbitrage Pricing Theory (APT), as well as the continuous time revolution in finance, closely associated to the name of Merton. This revolution paved the way for the Option Pricing Theory of Black and Scholes and its numerous extensions, and for rational pricing of all the new financial instruments created in the wake of the options approach to security analysis and corporate hedging. In the eighties the financial option paradigm and the microeconomics of information are merging into a comprehensive theory of contracts and agency problems.

Compared with these tremendous developments in microeconomics and finance, macroeconomic theory, as surveyed in Professor von Furstenberg's lecture, seems to lag behind by wide, at least as far as the treatment of risk and uncertainty is concerned. The main reason for this discrepancy is that the treatment of uncertainty in macroeconomics has not been endowed with a unifying principle from which all analyses could safely start. There are two principles of this kind in microeconomics. The first is the Expected Utility Paradigm (or Bernoulli principle) which - although occasionally criticized in the literature - still provides the foundation on which all meaningful modelling of individual behavior and market mechanisms is based. The second, more implicit and less subject to criticism, is the Principle of Exogeneity according to which uncertainty has fundamentally its source in the probabilistic occurrence of one state of nature among a set of states which are unaffected by the actions of individual decision makers. Even when problems of moral hazard arise, they are due to the fact that the individual firm or institution providing coverage for risk can only observe outcomes, and not the true combinations of exogenous states of nature and individual actions. The difficulty is that a given outcome may be the result of different state/ action mixtures. 
In macroeconomics, the Principle of Exogeneity is less acceptable. Of course, some analysis of the impact of exogenous shocks, such as natural catastrophes or political events, on the economy is possible. There is a large amount of literature on this topic, as indicated by the section on "Policy Surprises and Other Macroeconomic Disturbances" in Professor von Furstenberg's paper. But a real theory of public risk management, to be compared with the theory of corporate risk management at the micro level is still lacking. The reason for that is probably to be found in the partial endogeneity of the propagation mechanism. To quote Professor von Furstenberg: "Both the persistence of the original disturbances and the propagation mechanism combine to determine the persistence of macroeconomic fluctuations in ways difficult to disentangle". (p. 51).

In other words, and this is in my view the important point, when dealing with uncertainty in macroeconomics, the risk is never exogenous. There are no independent states of nature in the face of which economic policy could be optimally conducted. In macroeconomics, uncertainty arises from the system itself. It is the interaction between economic policy and those economic aggregates shaping the environment that creates uncertainty. To put it differently, uncertainty is not so much about events as about the structure of the economy and about the innovations in the aggregate behavior of actors and their response to changes in policy. There is a kind of Heisenberg principle in macroeconomics which makes more difficult any mechanical analysis of uncertain processes and might even doom it to failure. The money supply announcement puzzle investigated by Cornell [1983] provides a good example of the difficulties in modelling aggregate reactions.

For this reason, I don't think that the aggregation problem, extensively dealt with in section II of Professor von Furstenberg's paper should be considered an important building block of macroeconomic theory under uncertainty. In my opinion, macroeconomics is not a theory of aggregated individual behaviors and markets. This is rather a definition of general equilibrium analysis, and the latter is quite different from macroeconomics, as witnessed by the difficulties encountered in trying to set up microeconomic foundations for macroeconomics. Macroeconomic theory has only a meaning if one holds the philosophical view that in economics, as in music, painting, etc., the whole is generally something more than the sum of its parts. In impressionist paintings, a myriad of individually scattered colour spots interact to create a picture. By analogy, one could argue that in economics a great number of individual investment projects and decisions interact to produce an aggregate called investment expenditures.

In conclusion, I am not convinced that uncertainty is adequately incorporated in macroeconomics by now. There is no macroeconomics of uncertainty which could be compared to its microeconomic counterpart. A fact which comforts this argument is the poor stochastic content of the so-called Rational Expectations revolution in macroeconomics. In this theory, it is claimed that "...the average expectation about the state of the economy is an unbiased predictor of actual states..." (von Furstenberg and Jeong [1988], p. 35). Applied to the theory of foreign exchange, this has led to the obsolete view that the forward rate is an unbiased predictor of the expected future spot rate. But when uncertainty and behavior towards risk are not brushed under the carpet, risk premiums for stochastic inflation and for random deviations from purchasing power parity must be taken into account 
(see Adler and Dumas [1983]). This does not mean that there are no rational expectations. It means that uncertainty matters in explaining the discrepancy between current values of the variables and their expected future values.

The comprehensive survey of Professor von Furstenberg reinforces my impression that uncertainty is not really present in macroeconomics. It appears mainly in recent monetary models closely related to equilibrium models of the international financial market (e.g. Stulz [1986]) or in research trying to reconstruct macroeconomics from a micro perspective (see Hall and Taylor [1986]). We are still lacking a clear conception of what uncertainty in macroeconomics means and a unifying paradigm to deal analytically with this kind of uncertainty.

\section{REFERENCES}

ADLER, M. and B. DUMAS [1983] : "International portfolio choice and corporation finance : A synthesis". Journal of Finance, 38 (June 1983), 925-984.

COPELAND, T. and F. WESTON [1984] : Financial Theory and Corporate Policy, Addison-Wesley.

CORNELL, B. [1983] : "The money supply annoucement puzzle : Review and interpretation". American Economic Review, 73 (September 1983), 644-657.

FRENKEL, J. (Ed.) [1983] : Exchange Rates and International Macroeconomics. University of Chicago Press.

HALL, R. and J. TAYLOR [1986] : Macroeconomics. Norton

HEY, J. [1979] : Uncertainty in Microeconomics. Basic Blackwell.

HELPMAN, E. and A. RAZIN [1978] : A Theory of International Trade Under Uncertainty. Academic Press.

STULZ, R. [1986] : "Interest rates and monetary policy uncertainty". Journal of Monetary Economics, 17 (May 1986), 331-347.

VON FURSTENBERG, G. and J. JEONG [1988] : "Owning up to uncertainty in macroeconomics",The Geneva Papers on Risk and Insurance, 13 (January 1988), 12. 